Journal of Science Education Research

Journal homepage: www.journal.uny.ac.id/jser

\title{
Developing Physics SSP Based on the Problem Solving to Improve the Process Skills and Problem-Solving Ability
}

\author{
Mujib Ubaidillah ${ }^{1^{*}}$, Insih Wilujeng ${ }^{2}$ \\ ${ }^{1,}$ SMP N Karangmoncol Purbalingga, ${ }^{2,}$ Universitas Negeri Yogyakarta \\ Corresponding Author. Email: mujibubaidillah14@yahoo.co.id, insihuny@yahoo.co.id
}

Keywords:
SSP, science
process skills, and
problem solving
ability

Keywords:

SSP, science problem solving ability

\begin{abstract}
The research aimed to1) find out the expedience of physics Subject-Specific Pedagogy (SSP) based on the problem solving, and 2) improve the science process skills and problemsolving ability of grade X students of SMA N 7 Yogyakarta in electricity subject using the physics SSP based on the problem-solving. The particular research was a research and development using the 4-D development model consisting of 1) define, 2) design, 3) development, and 4) dissemination. The developed SSP was tested in a limited and extensive field trial. The sample of the limited field trial was 15 students, while in the extensive field trial consisted of 30 students in the control class and 29 students in the experimental class. The statistical analysis used multivariate analysis. The results were 1) The developed SSP, in terms of the syllabus, Lesson Plan, and worksheet, was in the excellent category, while the science process skills instrument test, problem-solving instrument test, and the textbook were in a good category, 2) The implementation of SSP for physics learning based on a problem solving had significant effect on improving the students science process skills and problem solving ability. The result of the multivariate test showed a significantly different effect between students that learn using the physics SSP based on the problem solving and students learn using the physics SSP based on the conventional model.
\end{abstract}

\section{INTRODUCTION}

Law number 20 article 3 of the national education system, stated, "The National Education functions to develop the capability, character, and civilization of the nation for enhancing its intellectual capacity, and is aimed at developing learners' potentials so that they become persons imbued with human values who are faithful and pious to one and only God; who possess morals and noble character; who are healthy, knowledgeable, competent, creative, independent; and as citizens, are democratic and responsible," (Ministry of National Education, 2004: 5). The article implies that there is a meaningful role of the teacher in learning. The teacher has an important role in developing students' abilities through learning. But, they should consider that the students have characteristics.
Teachers can use a variety of methods, strategies, learning models, media, and teaching materials to achieve predetermined learning goals. A reliable, valid and systematic learning tool can use to achieve the learning goals. To create meaningful interaction, the teacher is required to compile and present the material aiming the students can easily achieve the competencies. Schulman (Liversidge, 2009: 16) stated that "emphasizes the importance of teacher's subject knowledge in effective teaching." It emphasizes the importance of the teacher as a subject of knowledge to create effective learning.

Learning physics aims to gain experience in applying scientific methods through experiments or experiments, students test the hypotheses by designing experiments through instrument installation, sampling, processing and interpretation of data, and reporting the experimental results 
verbally and written. Carin \& Sund (1990: 2) explained that science covers two scopes; science as a product and science as a process. Science as a product is a collection of knowledge consisting of facts, concepts, and principles of science. Science as a process is the skills and attitudes possessed by scientists to achieve the science products.

Science process skills (KPS) are an approach in the learning process by providing an opportunity for students to find facts, and build concepts through activities or experiences as scientists. Scientists study natural phenomena using scientific processes, such as through observation, experiment, and rational analysis. The scientific attitude, for example, is objective and honest in collecting data. Scientists obtain findings and products in the form of facts, concepts, principles, and theories using scientific processes and attitudes (Collete \& Chiappetta, 2007: 30).

Goldstone \& Downey (2013: 130) classifies science process skills into two parts, first, basic science process skills consist of observation, inference, prediction, estimation, classification, and measuring skills. Second, the integrated process skill is a skill built through basic science skills. Integrated processes skill are more specialized and related to experiments. Chiapetta \& Koballa (2010: 132) stated that integrated science process skills consist of operational definitions, controlling variables, data interpretation, hypotheses, and experiments.

Harlen (2000: 20) stated that students need science process skills both in scientific inquiry and learning process. Learning physics should lead to the nature of physics and not emphasize knowledge as a product, but develop the ability to process, practice to solve the problems, and apply in real life.

Akinbola \& Afolabi (2010: 235) stated that "science process skills are cognitive and psychomotor skills employed in problem-solving." Science process skills involve cognitive and psychomotor skills. Cognitive is used because students use their minds to solve problems. Science process skills are aspects of intellectual activity by scientists in solving problems and determining science products. Psychomotor skills are seen in science process skills because the problem-solving process involves measurement, experiment planning, and experimentation.

Temiz (2006: 1007) stated that “...a multiple format instrument that included both a hands-on task and paper and pencil items could be successfully developed and used". Efforts to develop science process skills are by developing observation instruments for science process skills and test to measure science process skills.

Science process skills and thinking skills have a close relationship. Ismail \& Juhsoh (2000: 67) stated that, when a representation of science process skills allows involving the mechanism of problemsolving in cognitive processes, then, the use of logical thinking makes it possible to develop scientific knowledge. Surely, the thinking process of solving problems will involve science process skills. Science process skills are more developed if students are provided with problems to solve. Efforts to develop students' science process skills are by involving students actively in learning activities both in the classroom and in the laboratory.

Jacobsen, Eggen \& Kauchak (2009: 249) stated, problem-solving is a method of problembased learning. The teacher facilitates students to learn problem-solving through experiences. Problem-solving begins with a problem that must solve by students with teacher assistance. Students are given the authority to solve the problems. Here, students can develop thinking skills, finding solutions, design, analyze, and carry out experiments to solve problems.

Meinser (1999: 146) stated: "one model of problem-solving is called the scientific method". Means, a way to solve problems using the scientific method is through finding problems, formulating hypotheses, observing and conducting experiments, interpreting data and drawing conclusions. Problemsolving is seen as a fundamental part of science learning in schools.

Moore (2009: 177) stated that "problemsolving is the intentional elimination of uncertainty through direct experiences and under supervision." Means, students prepare to solve problems every day as an important function of the school, and a special curriculum which supports the learning with problem-solving approaches. The experience encourages the students smart at thinking and process skills needed for the success of problemsolving.

Gok (2010: 110) stated, "Problem solving has been acknowledged as a paradigm of complex cognition that is part of our everyday experience".

Killen (2007: 243) stated that problemsolving involves student activities, goals in learning and developing their thinking skills, and involving skills. Students use the ability to analyze situations, apply their knowledge to new situations, recognize differences between facts and opinions, and take objective decisions. Obviously, students can develop science process skills through problemsolving learning.

Marzano (2001: 201) stated, "Problem solving is a complex process that students will need to learn about and practice." In solving problems, students must produce and test the hypotheses associated with various solutions according to 
predictions. Problem solving is about how to find the best solution, not just a few solutions.

Markoczi \& Revak (2003: 17) stated, " Teaching methods influence school achievement, which determined by motivation and intelligence, teaching methods, in turn, develop interest and problem-solving thinking as well." Teachers can use learning models that can develop students' thinking skills and problem-solving.

Selçuk, Çalışkan \& Erol (2008: 157) stated: " problem-solving instruction could help students' problem-solving performance more than traditional problem-solving tasks." The solution to the problem is a solving problems method by following the procedure for problem-solving of learning syntax. Problem-solving becomes more effective than traditional learning. Problem-solving learning encourages the student activities in solving problems and realize each phase containing a complex process.

Polya (Muijs \& Reynolds, 2011: 152) stated; "The following sequence has been proposed for solving problems: (1) understanding and representing the problem, (2) selecting or planning the solution, (3) executing the plan, and (4) ) evaluating the results." Means, the sequences in problem solving are; understanding the problem, selecting or planning the solution, executing a plan, and evaluating the results.

Gangoso, et. al (2006: 101) stated that the advantages of problem-solving learning are; students who study physics using problem-solving models have better mastery the process of solving the problems and effectively improving student activities in solving the physics problems. Jonassen (2006: 139) stated the benefits of problem-solving learning; 1) When students learn to solve engineering problems, students will learn to connect something they do not know into an equation, solve the equation to find results, and check the results, 2) there is an implicit relationship that problem-solving is a procedure involving memory, practice, and habituation, and a process emphasizing the acquisition of answers to be more meaningful.

Subject-specific pedagogy (SSP) is the packaging of material into a comprehensive and educational learning tool. The teacher conducts material analysis, analyzes student characteristics, analyzes concepts in determining learning devices. Material characteristics determine the learning method. Especially for material uses special teaching methods. Dynamic electrical material is a material containing procedural problem-solving. Procedural problem solving might deliver to students using problem-solving. Learning tool in electricity material is dynamically designed based on problem-solving.
The SSP has a close relationship with the Pedagogical Content Knowledge (PCK). To realize good learning, teachers must master the material and teaching. PCK is divided into two parts; Content Knowledge (CK) and Pedagogical Knowledge (PK). Mishra \& Koehler (2006: 1026) explained the Content knowledge (CK) is knowledge about the actual subject matter that is to be learned or taught.

According to Mishra \& Koehler (2006: 1026), Pedagogical knowledge (PK) is deep knowledge about the processes and practices or methods of teaching and learning and how it encompasses, among other things, overall educational purposes, values, and aims.

Goldstone (2004: 12) explained the importance of PCK in science which are the science teachers who succeed in using a pedagogical strategy. They learn how to reflect planning, and select and organize the content of science and pedagogy to provide meaningful learning for students. That is the essence of pedagogical content knowledge. In general, PCK focuses on the ability and expertise of teachers to create effective, meaningful, and educational learning for their students.

The observations at SMAN 7 Yogyakarta found out the physics learning tended to emphasize mastery of the material and did not emphasize the mastery of science process skills, need to solve the problems related to students' science process skills and problems of science process skills such as measurement skills, students' ability to make graph, interpret experimental data, and plan experiments. Physics learning emphasizes the physics problems solving procedurally have not used in learning. Learning tools developed by teachers tend to emphasize cognitive aspects, and not emphasized science process skills optimally.

The problem statements in this particular study were (1) what are the expedience of physics Subject-Specific Pedagogy (SSP) based on the problem solving to improve the science process skill and problem-solving, and 2) what are the physics Subject-Specific Pedagogy (SSP) based on the problem-solving in improving the science process skills and problem-solving ability of grade $\mathrm{X}$ students of SMA N 7 Yogyakarta in electricity subject. The research aimed to1) find out the expedience of physics Subject-Specific Pedagogy (SSP) based on the problem solving, and 2) improve the science process skills and problem-solving ability of grade X students of SMA N 7 Yogyakarta in electricity subject using the physics SSP based on the problem-solving. 


\section{METHOD}

Research Type

The particular research used Research and Development (R \& D) research methods. The developmental model was adapted from the 4D model developed by Thiagarajan (1974: 5) consisting of four stages; 1) define, 2) design, 3) develop, and 4) disseminate.

Time and Place of Research

The research conducted at SMAN 7 Yogyakarta from March to May 2013.

Target/Subject of the Research

The trial subject was students of grade $\mathrm{X}$ at SMAN 7 Yogyakarta at Second Semester. The limited trial subjects were 15 students of grade $X$ of SMA N 7 Yogyakarta that were randomly selected. The subjects of the trial were 30 students of class X.1 as Control Class and 29 students of class X.6 as Experiment Class.

Procedures

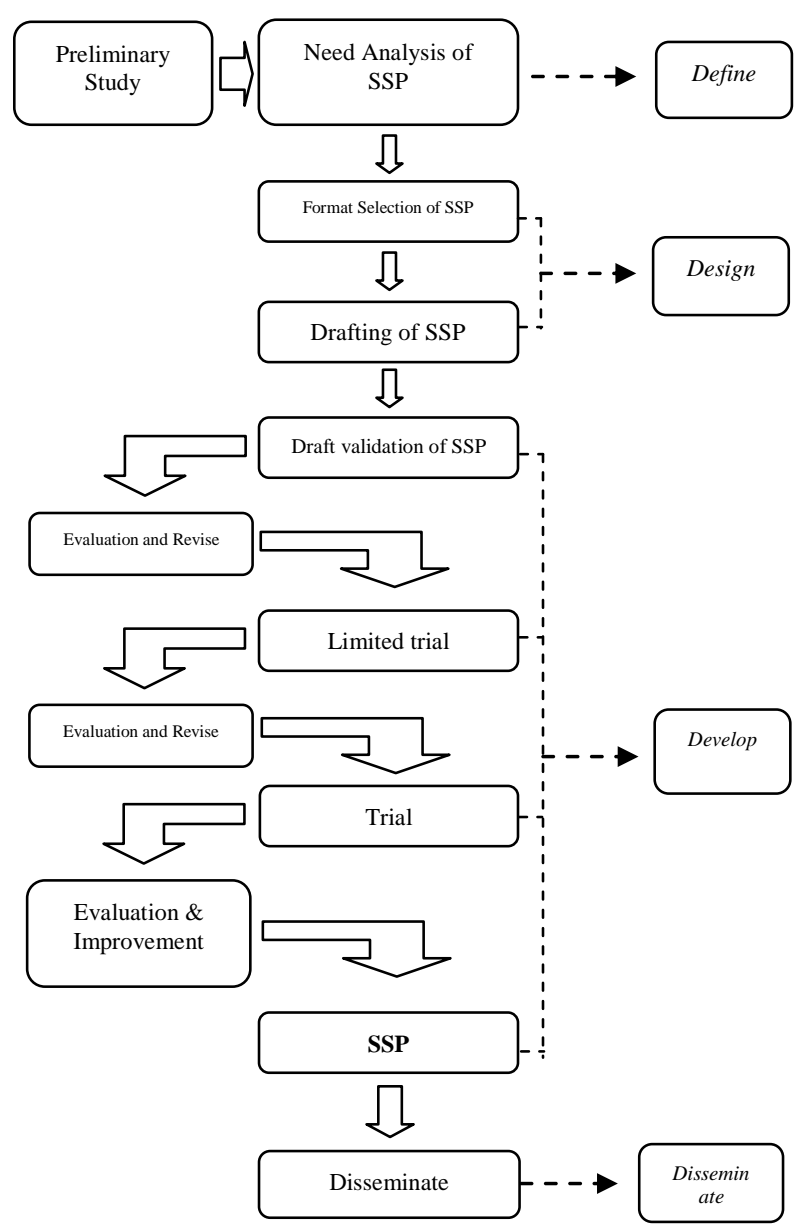

Figure.1 Developmental Procedure

Data, Instrument, and Data Collection Technique

Data were both quantitative and qualitative form. The data collection instruments were a form of SSP validation sheets, questions of science process skills, problem-solving ability, observation sheets for implementation of the lesson plan, and observations of science process skills.

Data Analysis Techniques

Result of Assessment Analysis of SSP Feasibility

Data analysis technique for SSP feasibility conducted through with the following steps:

1) tabulation of all data from the valuator for each component and sub-component of the assessment items available in the assessment instrument.

2) calculate the mean of each component using the formula:

$\bar{X}=\frac{\sum X}{n}$.

Where:

$X$ = Mean

$\sum X=$ Total of Score

$n=$ Number of valuator

3) convert the mean into the value with the criteria

The mean from valuator converted into qualitative data of five-scales on table 1 .

Table 1. Conversion of Actual Score into FiveScales

\begin{tabular}{lccc}
\hline No. & Range of score $(\mathrm{i})$ & Value & Category \\
\hline 1. & $X>x+1,80 \mathrm{Sb} i$ & $\mathrm{~A}$ & Excellent \\
2. & $x+0,60 \mathrm{SB} i<X$ & $\mathrm{~B}$ & Good \\
& $\leq x+1,80 \mathrm{Sb} i$ & & \\
3. & $x-0,60 \mathrm{SB} i<X$ & $\mathrm{C}$ & Pretty \\
& $\leq x+0,60 \mathrm{Sb} i$ & & Good \\
4. & $x-1,80 \mathrm{SB} i<X$ & $\mathrm{D}$ & Poor \\
5. & $\leq x-0,60 \mathrm{Sb} i$ & & Very Poor
\end{tabular}

(Sukardjo, 2008: 83)

Where:

$X=$ actual score (achieved score)

$x=$ mean of ideal score

$=(1 / 2)$ (ideal highest score + ideal lowest score $)$

$S B i=$ standard deviation ideal score

$=(1 / 2)(1 / 3)$ (ideal ideal highest score - ideal lowest score)

Ideal ideal highest score $=\Sigma$ item criterion $\times$ highest score.

Ideal lowest score $=\Sigma$ item criterion $\times$ lowest score .

Analysis of learning implementation

This analysis carried out by calculating the mean given by the observer with the following criteria: 
Table 2. Score of Lesson Plan Implementation

\begin{tabular}{cccc}
\hline No & Range of score (i) & Value & Criteria \\
\hline 1. & $3,25 \leq \bar{M} \leq 4,00$ & A & Excellent \\
2. & $2,50 \leq \bar{M}<3,25$ & B & Good \\
3. & $1,75 \leq \bar{M}<2,50$ & C & Enough \\
4. & $1,00 \leq \bar{M}<1,75$ & D & Poor \\
\hline
\end{tabular}

(Ministry of National Education, 2010: 60)

The following formula used to calculate the percentage of reliability of the lesson plan implementation.

$$
R=\left(1-\frac{\mathrm{A}-\mathrm{B}}{\mathrm{A}+\mathrm{B}}\right) \times 100 \%
$$

Where:

$\mathrm{R}=$ percentage of lesson plan implementation

$\mathrm{A}=$ Highest score given by observer

$\mathrm{B}=$ Lowest score given by observer

Analysis of improving process skills and problem solving skill

The results of the test were science process skills and problem-solving abilities. Standard gain used to see an increase in the mean of the pretestposttest score. Calculation of standard gain refers to equation 12 (Meltzer, 2002: 1260). The equation is:

Standard Gain $=\frac{\text { Posttest Score }- \text { Pretest Score }}{\text { Maximum Score-Pretest Score }}$.

Analysis of achievements test of science process skills and problem solving abilities

Normality Test

Normality test conducted using Kolmogorov Smirnov with significance level of 0.05 .

Homogeneity Test

The homogeneity test of the variance of each dependent variable was used the Levene statistical test with a significance level of 0.05 .

Homogeneity Test of Covariant matrices

The homogeneity test of covariance matrices was carried using Box's $M$ test, with a significance level of 0.05 .

\section{Correlation Test}

Correlation test aims to find out the relationship between dependent variables. Correlation tests carried out using the Pearson Correlation test.

Test of Multivariate/Hotelling's $\mathrm{T}^{2}$

SSP based on problem-solving is an independent variable; meanwhile, problem-solving skills and science process skills are dependent variables. The statistical test carried out using Multivariate Test / Hotelling's $\mathrm{T}^{2}$ with a significance level of 0.05 . The Multivariate Test / Hotelling $\mathrm{T}^{2}$ carried out with the help of SPSS 16 for Windows. The decision criteria were; $\mathrm{H} 0$ rejected if $\mathrm{F}_{\text {counts }}>$ $\mathrm{F}_{(\alpha)(\mathrm{p})(\mathrm{n} 1+\mathrm{n} 2-\mathrm{p}-1)}$ or significance value $<0.05$. The research hypotheses are:

$\mathrm{H}_{0}=$ there is no significant difference in the mean score of improvement the science process skills and problem-solving abilities between students learning using SSP physics based on problem-solving and conventional method.

$\mathrm{H}_{1}=$ there is no significant difference in the mean score of improvement the science process skills and problem-solving abilities between students learning using SSP physics based on problem-solving and conventional method. The hypothetical statistics of the research were;

$\mathrm{H}_{0}:\left(\begin{array}{l}\mu_{11} \\ \mu_{21}\end{array}\right)=\left(\begin{array}{l}\mu_{12} \\ \mu_{22}\end{array}\right)$
$\mathrm{H}_{1}:\left(\begin{array}{l}\mu_{11} \\ \mu_{21}\end{array}\right) \neq\left(\begin{array}{l}\mu_{12} \\ \mu_{22}\end{array}\right)$

\section{RESULT}

Validation Result of SSP

Table 3. Data of Syllabus Validation Result

\begin{tabular}{clcl}
\hline No & \multicolumn{1}{c}{ Valuator } & Score & \multicolumn{1}{c}{ Category } \\
\hline 1. & Expert I & 26 & Excellent \\
2. & Expert II & 24 & Good \\
3. & Physic Teacher & 27 & Excellent \\
Mean & & 25,67 & Excellent \\
\hline
\end{tabular}

Table 4. Data of Validation Result of Lesson Plan

\begin{tabular}{llcl}
\hline No & \multicolumn{1}{c}{ Valuator } & Score & Category \\
\hline 1. & Expert I & 97 & Excellent \\
2. & Expert II & 96 & Excellent \\
3. & Physic Teacher & 95 & Excellent \\
Mean & 96 & Excellent \\
\hline
\end{tabular}

Table 5. Data of Validation Result of KPS Question

\begin{tabular}{cccl}
\hline No & \multicolumn{1}{c}{ Valuator } & Score & Category \\
\hline 1. & Expert I & 59 & Excellent \\
2. & Expert II & 56 & Good \\
3. & Physic Teacher & 60 & Excellent \\
Mean & 58.33 & Good \\
\hline
\end{tabular}

Table 6. Data of Validation Result of KPM Question

\begin{tabular}{clcl}
\hline No & Valuator & Score & Category \\
\hline 1. & Expert I & 52 & Good \\
2. & Expert II & 51 & Good \\
3. & Physic Teacher & 49 & Good \\
Mean & 50.67 & Good \\
\hline
\end{tabular}


Table 7. Data of Validation Result of Student Worksheet

\begin{tabular}{clcl}
\hline No & Valuator & Score & Category \\
\hline 1. & Expert I & 111 & Good \\
2. & Expert II & 112 & Good \\
3. & Physic Teacher & 114 & Good \\
Mean & 112.33 & Excellent \\
\hline
\end{tabular}

Table 8. Data of Validation Result of Teaching Material

\begin{tabular}{cccc}
\hline No & Valuator & Score & Category \\
\hline 1. & Expert I & 45 & Good \\
2. & Physic Teacher & 43 & Good \\
Mean & 44 & Good \\
\hline
\end{tabular}

Data of Limited Trial Test

Table 9. Recapitulation of students' responses to students worksheet

\begin{tabular}{clcl}
\hline No & Assessed Aspect & Mean & Category \\
\hline 1. & Content/Material & 38,89 & Good \\
2. & Language & 6,50 & Good \\
3. & Presentation & 6,25 & Good \\
4. & Clarity & 17,38 & Very Clear \\
\hline
\end{tabular}

Table 10. Recapitulation of students' responses to learning material

\begin{tabular}{clcl}
\hline No & Assessed Aspect & Mean & Category \\
\hline 1. & Content/Material & 15,00 & Good \\
2. & Language & 6,31 & Good \\
3. & Presentation & 11,89 & Good \\
\hline
\end{tabular}

Empirical Trial Test of KPS Question

The result of reliability of instrument on science process skill was 0.842 . The instrument of science process skill is reliable. The result is presented in table 11.

Table 11. Reliability of Instrument Test of Science Process Skills

\begin{tabular}{cc}
\hline Cronbach's Alpha & N of Items \\
\hline 0,842 & 30 \\
\hline
\end{tabular}

The reliability of the instrument test on the problem-solving ability was 0.811 and classified reliable. The reliability results of the problemsolving ability instruments are presented in Table 12.

Tabel 12. Reliability of Problem Solving Ability Tests
The implementation of learning

The trial of the learning implementation in the classroom was observed by two observers. The learning is performed in four meetings. Instruments for implementation used for observations. Each observer observes the aspects of learning. Observation, in the first part, includes aspects of the preliminary activities, core activities, and closing activities. The second part of the observation is class management. The core activity contains the syntax of the problem-solving learning model.

Table 13. Implementation of Science learning of Lesson Plan

\begin{tabular}{|c|c|c|c|c|}
\hline \multirow{2}{*}{ No } & \multirow{2}{*}{ Meeting } & \multicolumn{2}{|c|}{ Average Score } & \multirow{2}{*}{ Category } \\
\hline & & P1 & P2 & \\
\hline 1. & Meeting 1 & 4,00 & 3,86 & Excellent \\
\hline 2. & Meeting 2 & 3,91 & 3,82 & Excellent \\
\hline 3. & Meeting 3 & 3,82 & 3,95 & Excellent \\
\hline 4. & Meeting 4 & 3,82 & 3,68 & Excellent \\
\hline
\end{tabular}

Test Results of Science Process Skills and Problem Solving Abilities

The subjects were 30 students in the control class and 29 students in the experimental class. Based on the pretest-posttest control group design in the trial test, the assessment was conducted twice; before the treatment (pretest) and after treatment (posttest). The gain standard was used to find out the differences between pretest and posttest. Using the standard gain technique is based on the fact that increasing a high score is more difficult than increasing poor score of the student.

Table 14. Pretest-Posttest Score of Science Process Skills

\begin{tabular}{clccc}
\hline No & \multicolumn{1}{c}{ Class } & Pretest & Posttest & Gain \\
\hline 1. & $\begin{array}{l}\text { Control } \\
\text { (X.1) }\end{array}$ & 57 & 70 & 0,29 \\
2. & $\begin{array}{l}\text { Experiment } \\
\text { (X.6) }\end{array}$ & 71 & 86 & 0,48 \\
\hline
\end{tabular}

Table 15. Pretest-Posttest Score of Problem Solving Ability

\begin{tabular}{clccc}
\hline No & \multicolumn{1}{c}{ Class } & Pretest & Posttest & Gain \\
\hline 1. & $\begin{array}{l}\text { Control } \\
\text { (X.1) }\end{array}$ & 54 & 71 & 0,36 \\
2. & $\begin{array}{l}\text { Experiment } \\
\text { (X.6) }\end{array}$ & 64 & 82 & 0,49 \\
\hline
\end{tabular}

\begin{tabular}{cc}
\hline Cronbach's Alpha & N of Items \\
\hline 0,811 & 21 \\
\hline
\end{tabular}


Analysis of Product Evaluation

Syllabus

The data in Table 3 showed that the syllabus, results of development phase; according to expert I, obtained a score of 26 with an excellent category; according to experts II, obtained a score of 24 with a good category; physic teachers provided a score of 27 with an excellent category. The maximum score for the syllabus validation was 30 .

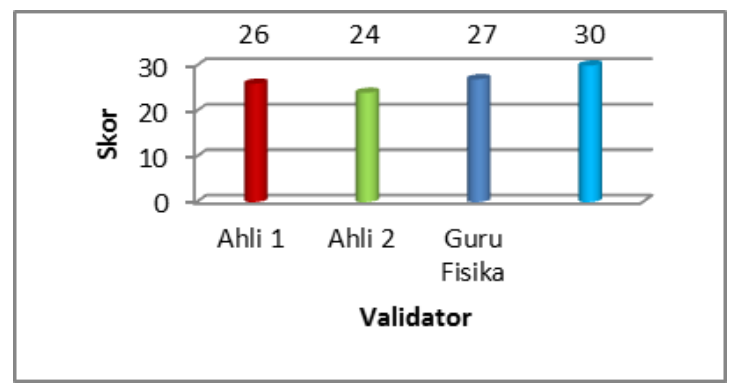

Figure 2. Diagram of Syllabus Validation

\section{Lesson Plan}

The validation of the lesson plan obtained a score of 96 with an A "excellent" which aimed to improve science process skills and problem-solving abilities. The maximum score of this validation was 110. Based on the validation, the lesson plan is feasible to use in learning.

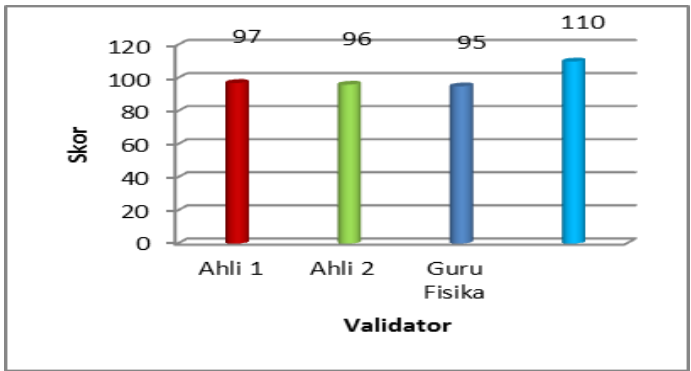

Figure 3. Diagram of Lesson Plan Validation from expert and physic teacher

Instrument of Science Process Skill Test

Results the validation of the instrument of science process skills were; aspects of content/material, language, and presentation. The results showed that the instrument is feasible with excellent categories. The maximum score for the assessment was 70 .

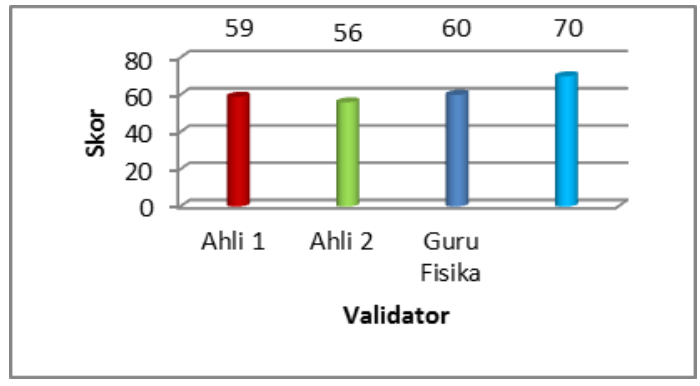

Figure 4. Diagram of Instrument Validation for science process skills from expert and physic teacher

Instrument of Problem Solving Ability Test

The problem-solving ability test instrument was compiled to measure students' ability to solve dynamic electricity problems. The items contained indicators of problem-solving. The instrument validation included 3 aspects; content/material, language, and presentation.

The validation from 2 experts and physics teacher showed that the problem-solving ability test instrument obtained a good predicate with a mean score of 50.67. The maximum score was 65 .

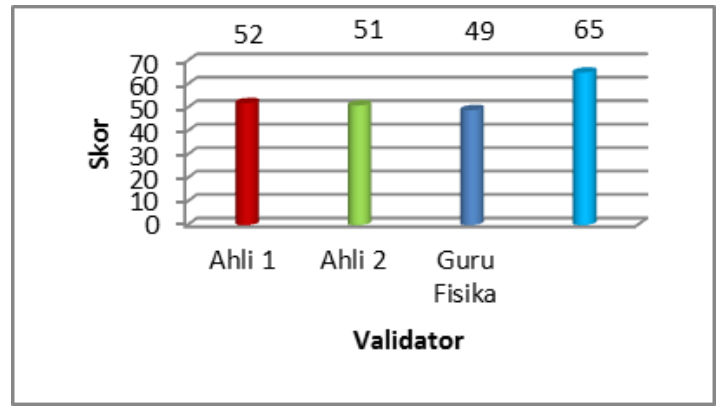

Figure 5. Diagram of Instrument Validation for problem solving ability from expert and physic teacher

\section{Student Worksheet}

The student worksheet validation assessed on didactic and construction aspects. 2 experts and physics teacher provided a mean score of 112.33 in the "good" category. There are 27 items in the evaluation aspects of syllabus validation. The score was from 1-5 and the maximum score was 135 .

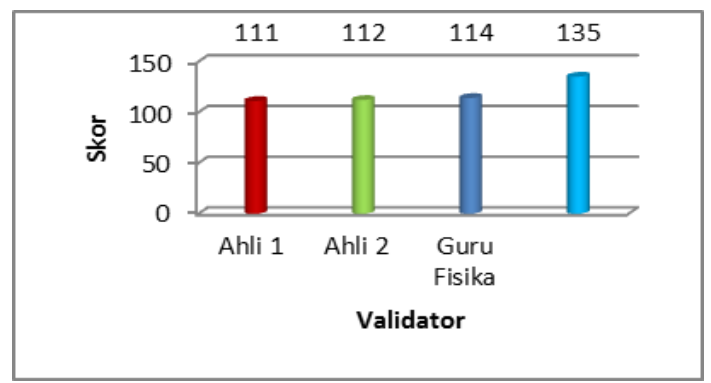

Figure 6. Diagram of Student Worksheet Validation from expert and physic teacher

Teaching materials

The developed teaching materials were tested to 15 students. The data in Table 22 showed; expert I provided score of 22 or A "excellent" category for 
the content/material, score of 7 or B value "good" for language aspect, and score of 16 or B "good" for presenting aspect. The total score of validation for teaching materials from an expert I was 45 in the good category. Physics teacher provided score of 19 or B "good" category for the content/material, score of 7 or B value "good" for language aspect, and score of 15 or B "good" for presenting aspect. The total score of validation for teaching materials from physics teacher was 43 in the good category. The mean of physics experts and teachers is 44 or good category. The maximum score for teaching material validation is 55 . Figure 7 is a diagram from the results of the validation of teaching materials.

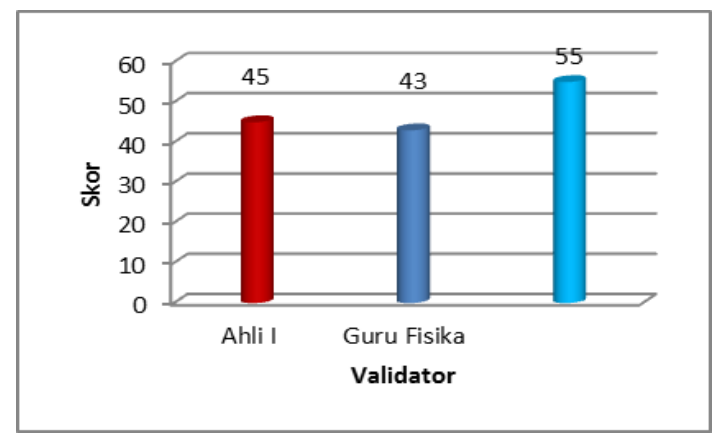

Figure 7. Diagram of Teaching Material Validation from expert and physic teacher

\section{Analysis of Limited Trial}

Questionnaire for Student Worksheet readability of student worksheet

The results of student questionnaire responses to student worksheet showed that student worksheets might understand well by students in terms of content, language, and presentation. Assessment of the readability of student worksheet by students becomes an input to conduct an extended experiment.

Questionnaire for the Readability of Teaching Materials

The results of the student questionnaire responses to the readability of teaching materials obtained good category. Assessment of teaching materials included in the aspects of content in good categories, aspects of language in good categories, and aspects of presentation in good categories.

\section{Analysis of Extended Test}

Implementation of Lesson Plan

Based on data of observation, lesson plan based on problem-solving models conducted four times. The percentages of implementation were; reach $98 \%$ in the first meeting, $99 \%$ in the second meeting, $98 \%$ in the third meeting, and $98 \%$ in the fourth meeting. The implementation classified as an excellent and reliable category. Figure 8 is a diagram of the lesson plan implementation in learning.

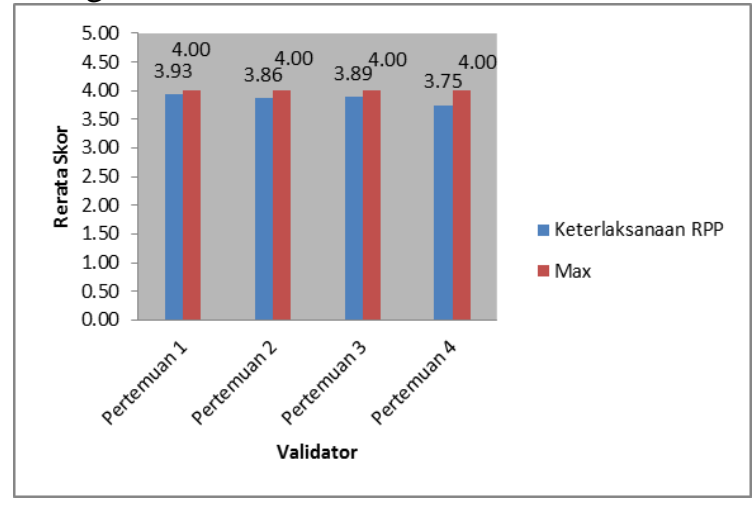

Figure 8. Diagram of lesson plan implementation

Analysis of Science Process Skill in Learning

Science process skills that arise during the learning process are observed using observation sheets of science process skills and assessment rubrics. Observations were carried out by four teachers. The science process skills observed during the learning process were the use of electrical measuring instruments, identification of variables, formulation of hypotheses, formulation of problems, designing experiments, making a chart, making tables, interpretations, and concluding abilities.

The analysis results showed that the mean score of science process skills was 3.59 in excellent categories for the experimental class and 2.53 in good category for control class. The maximum score for each aspect of science process skills is 4.00. Data on science process skills of students in practical activities used as supporting data. Data obtained from experiments on electrical measuring devices, ohm laws, conductor type barriers, series barriers, and parallel barriers.

Data from observation stated that the mean scores of science process skills in the control class were; 0.000 on the aspects of hypothesis formulation, 0.47 on the aspect of variable identification, and 0.41 on the aspect of prediction. Meanwhile, in the experimental class, the mean score of science process skills were; 3.50 on the aspects of hypothesis formulation, 3.89 on the aspect of variable identification, and 3.48 on the aspect of prediction. There was a gap in term of mean score of science process skills between the control class and the experiment class. Worksheets used for treatment was different between control and experiment class. Worksheet with problemsolving based was used in the experimental class. In contrast, conventional worksheet was used in the control class. Worksheet in the control class had no aspect of the hypothesis formulation so that the value was 0.00 . Prediction and identification aspects of variables in the control class are only found in the 
conductor type barrier practice, so the mean score of prediction and identification aspects of the variables are very poor.

\section{Analysis of Science Process Skills}

Measurement of science process skills used multiple-choice questions test. The questions were 22 items. The items represented the indicators of science process skills. In the field trials, the score of science process skills in the experimental class has increased by 15; the completeness of students in the posttest was $93.33 \%$. Meanwhile, the score of science process skills in the control class has increased by 13; the completeness of students in the posttest was $36.67 \%$. The diagram of completeness of the science process skill test is presented in Figure 17 and Figure 18.

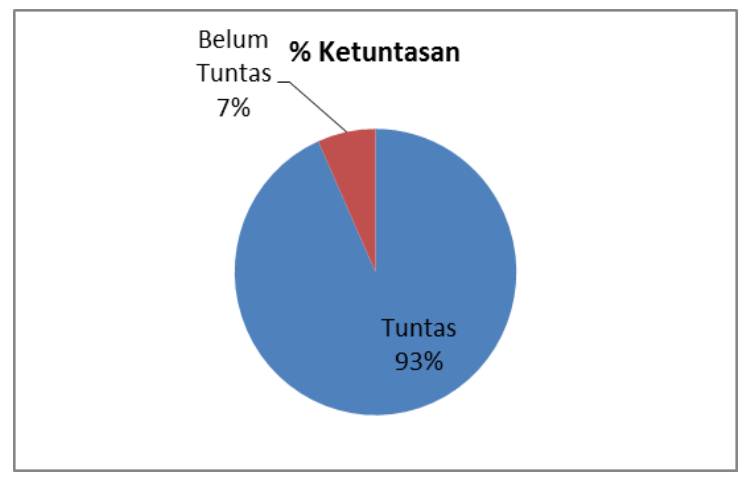

Figure 9. Diagram of science process skill completeness in the experiment class

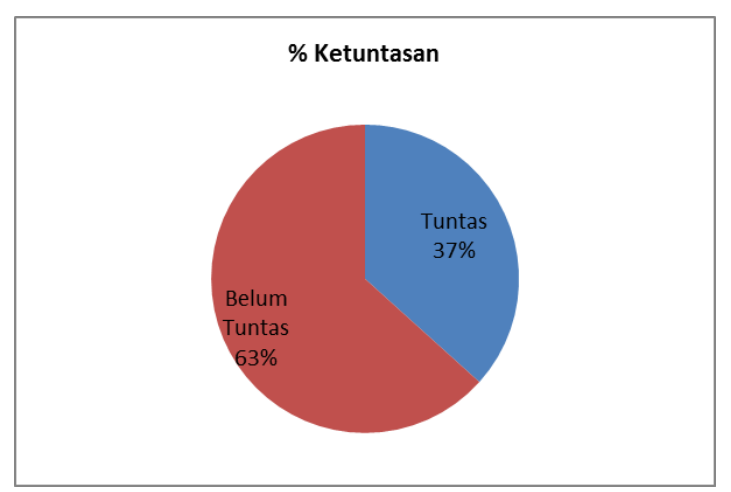

Figure 10. Diagram of science process skill completeness in the control class

Analysis of Problem solving ability test Value Analysis of Problem Solving Ability Test Data

16 items of multiple-choice questions were used to measure the problem-solving ability on dynamic electrical material. The indicator of competency achievement is the students score compared to the minimum completeness criteria (KKM). KKM in SMAN 7 Yogyakarta for physics subjects is 75 . Means, every student have mastered competence standard when they have reached a minimum score of 75 .

In the field trials, the score of problemsolving in the experimental class increased by 18 , and the completeness of students in the posttest was $83.33 \%$. Meanwhile, the score of problem-solving in the control class increased by 17 , and the completeness of students in the posttest was $53.33 \%$. The diagram of the completeness score of the problem-solving ability test is presented in Figure 19 and Figure 20.

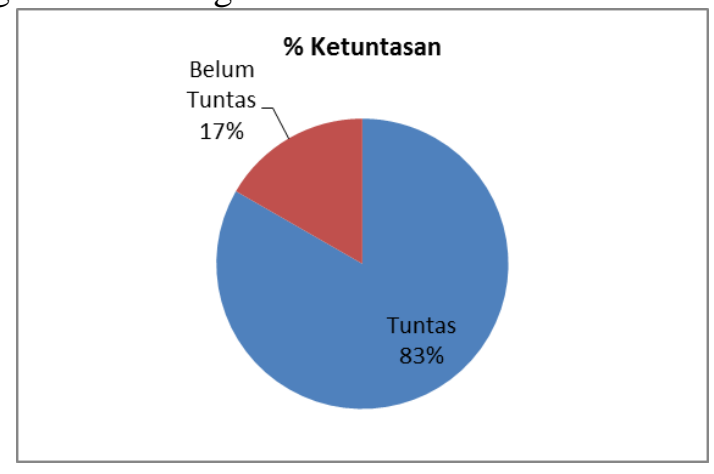

Figure 11. Diagram of completeness score of the problem-solving ability in the experiment class

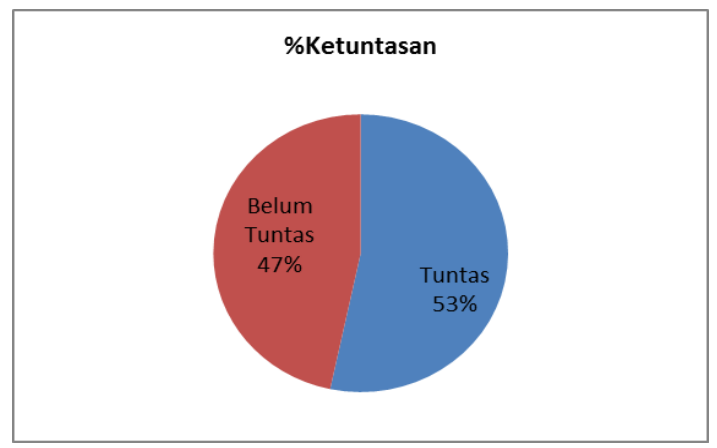

Figure 12. Diagram of completeness score of the problem-solving ability in the control class

Analysis of Problem Solving ability and Problem Solving in learning

Multivariate analysis used to analyze the effect of physics SSP-based problem solving on science process skills and problem-solving abilities. The use of multivariate analysis aims to determine the effect of an independent variable (SSP based on problem-solving) on two dependent variables (science process skills and problem-solving abilities). The multivariate analysis step must pass through the assumption test including normality, homogeneity, homogeneity of covariance matrics, Pearson correlation, and multivariate test. If the requirements for the multivariate test fulfilled, it continues to multivariate test. 
Normality

The normality test is used to find out the sample whether normal distributed or not. The technique in the normality test was KolmogorovSmirnov with a significance level of 0.05 . The hypotheses were:

$\mathrm{H}_{0}=$ Sample is normally distributed

$\mathrm{H}_{1}=$ Sample is not normally distributed

The following is a summary of the normality test using SPSS 16 for Windows.

Table 16. Summary of Kolmogorov-Smirnov test

\begin{tabular}{llcc}
\hline Class & \multirow{2}{*}{$\begin{array}{c}\text { Dependent } \\
\text { Variable }\end{array}$} & \multicolumn{2}{c}{$\begin{array}{c}\text { Kolmogorov- } \\
\text { Smirnov }\end{array}$} \\
& & Statistic & Sig. \\
\hline KE & KPS & 0,114 & 0,200 \\
(X.6) & KPM & 0,149 & 0,097 \\
KK & KPS & 0,131 & 0,198 \\
(X.1) & KPM & 0,139 & 0,141 \\
\hline
\end{tabular}

The science process skills, the control class students who use the conventional method, obtained the sig value $0.198>0.05$. Science process skills, the experiment class students who use SSP based on problem-solving, obtained the sig value 0.200> 0.05 . The hypothesis $\mathrm{H} 0$ accepted because all components have a sig. $>0.05$. Meaning, the sample data are normally distributed. Then, it continues to MANOVA test.

\section{Homogeneity}

The homogeneity test is used to find out the homogenous of the two groups of sample data with the assistance of SPSS 16 for windows. The hypotheses for the homogeneity test were;

$\mathrm{H} 0=$ Homogenous .

$\mathrm{H} 1=$ Not homogenous.

Table 17. Summary of homogeneity test of science process skill and problem solving ability

\begin{tabular}{cccc}
\hline No & $\begin{array}{c}\text { Dependent } \\
\text { variable }\end{array}$ & $\begin{array}{c}\text { Levene } \\
\text { Statistic }\end{array}$ & Sig. \\
\hline 1. & KPM & 0,129 & 0,721 \\
2. & KPS & 0,182 & 0,671 \\
\hline
\end{tabular}

Criteria for the hypothesis test of $\mathrm{H}_{0}$ accepted if the sig. value $>$ than 0.05 . Tests using Levene statistics, data in Table 17, obtained a score of 0.721 for science process skills. The score was higher than 0.05 . And, tests using statistical Lavene obtained significance for problem-solving abilities of 0.671 , higher than 0.05. Because sig $>\alpha$, then $\mathrm{H}_{0}$ accepted.
So, the variance in each group is homogeneous. Means, research data is homogeneous and continued to MANOVA.

\section{Homogeneity of the Covariance Matrices}

MANOVA requires the homogeneity of variance/covariance matrices on the dependent variable. Homogeneity of covariance matrices is an assumption test of MANOVA. The assumption is fulfilled if the value is sig. $>0.05$. The hypotheses of covariance matrix test are:

$\mathrm{HO}=$ variance $/$ covariance matrices of the dependent variable is homogenous

$\mathrm{H} 1$ = variance $/$ covariance matrices of the dependent variable is not homogenous

Analysis results using SPSS 16 for windows to test the homogeneity of covariance matrices is seen from the results of the Box's M test.

Table 18. Summary of Box's M Test

\begin{tabular}{cccc}
\hline Box's M & F & $d f 1$ & Sig. \\
\hline 0,180 & 0,058 & 3 & 0,982 \\
\hline
\end{tabular}

Pearson Correlation

The MANOVA test requires a correlation test to find out the correlation between dependent variables. The variables are process skills and problem-solving abilities. The hypotheses are:

$\mathrm{H}_{0}=$ there is no relationship between science process skills and problem-solving abilities

$\mathrm{H}_{1}=$ there is a relationship between science process skills and problem-solving abilities

Table 19. KPS and KPM Correlation Test Results

\begin{tabular}{cccc}
\hline $\begin{array}{c}\text { Dependent } \\
\text { Variable }\end{array}$ & $\begin{array}{c}\text { Pearson } \\
\text { Correlation }\end{array}$ & $\mathrm{N}$ & Sig. \\
\hline KPM-KPS & 0,266 & 59 & 0,045 \\
\hline
\end{tabular}

Data in Table 19, the r-value of the Pearson correlation is 0.266 at the 0.05 of the significance level. The $\mathrm{r}$ table for $\mathrm{N}=59$ at the 0.05 significance level is 0.256 . So, $r$ count $>\mathrm{r}$ table, then $\mathrm{H} 0$ rejected, Means, there is a significant relationship between science process skills and problem-solving abilities.

\section{Multivariate / Hotelling's T2 Test}

After the requirement for hypothesis test fulfilled, it continued to MANOVA hypothesis test. The MANOVA test is used to test the differences dependent variables between groups. Decisions are taken with multivariate / Hotelling Trace analysis. The results of the analysis for research data using SPSS 16 for Windows are;

$\mathrm{H}_{0}=$ there is no significant difference in the mean score improvement of science process skills and 
problem-solving abilities between students learning using SSP physics based on problem-solving and conventional method.

$\mathrm{H}_{1}=$ there is significant difference in the mean score improvement of science process skills and problemsolving abilities between students learning using SSP physics based on problem-solving and conventional method.

The statistical hypotheses of this study were:

$$
\begin{aligned}
& \mathrm{H}_{0}:\left(\begin{array}{l}
\mu_{11} \\
\mu_{21}
\end{array}\right)=\left(\begin{array}{l}
\mu_{12} \\
\mu_{22}
\end{array}\right) \\
& \mathrm{H}_{1}:\left(\begin{array}{l}
\mu_{11} \\
\mu_{21}
\end{array}\right) \neq\left(\begin{array}{l}
\mu_{12} \\
\mu_{22}
\end{array}\right)
\end{aligned}
$$

The summary of the Multivariate test using SPSS 16 for windows is presented in Table 20.

Table 20. Result of Hotelling's Trace test on science process skill and KPM

\begin{tabular}{cccc}
\hline Effect & F & $\begin{array}{c}\text { Hypothesis } \\
\text { df }\end{array}$ & Sig. \\
\hline $\begin{array}{c}\text { Hotelling's } \\
\text { Trace }\end{array}$ & $9,839^{\mathrm{a}}$ & 2,000 & 0,000 \\
\hline
\end{tabular}

Criteria for the hypothesis test of $\mathrm{H} 0$ accepted if the sig. value $>0.05$ and Ho rejected if the sig. values $<0.05$. Manova test data with the help of SPSS 16 for windows showed that the price of $F$ Hotelling Trace, the learning model has a significance score lower than 0.05 . Means, the price of $\mathrm{F}$ for Hotelling Trace is significant. Then, H0 rejected. In sum, there are differences in process skills and problem-solving ability between students learning with conventional and problem-solving learning models.

\section{CONCLUSION}

\section{Conclusion}

Based on the results of the research and development of SSP product based on problemsolving learning models, concluded:

1. The particular research produces an SSP product based on problem-solving learning models. The SSP components consist of the syllabus, lesson plans, worksheets, science process skills test instruments, problemsolving ability test instruments, and teaching materials. The methods for developing SSP products and evaluating SSP quality based on expert validation results and field trials are:

a. SSP development at the define stage consists of Front-end analysis, student analysis, material analysis, concept analysis, and specification of learning objectives. Material analysis aims to determine SK-KD. Delivery material uses a specific method. Characteristics of the material determine the learning method. Characteristics of dynamic electrical material are procedural problemsolving skills and taught using problemsolving.

b. The developed SSP product is used to improve science process skills and problemsolving abilities. The validation of syllabus, lesson plans, student worksheets, obtains excellent category. And, the validation of science process skills test instruments, problem-solving ability test instruments, and teaching materials according to experts and physics teachers, also obtains good criteria.

c. The implementation of physic learning using SSP models in the extended trial is very well implemented.

2. SSP Physics based on problem-solving can improve science process skills and problemsolving ability on dynamic electrical material at grade X students of SMA N 7 Yogyakarta.

a. The level of achievement of science process skills by applying SSP based on problemsolving is $93.33 \%$ achieving the completeness criteria.

b. The score of completeness criteria of physics problem solving is $83.33 \%$ by applying SPP based on problem-solving.

c. The implementation of SSP physics based on problem-solving affects improving science process skills and increasing the problemsolving ability on dynamic electricity topic. There are significant differences in the mean of science process skills and problem-solving abilities between students learning using SSP physics-based problem solving and conventional devices.

\section{Suggestions}

The particular study proposes suggestions (a) developed SSP physics might be used by physics teachers to develop, and improve students' science process skills and problem-solving abilities, (b) developed of SSP physics products allows to disseminate, especially in SMAN 7 Yogyakarta, such as cross-grade physics teacher, and science teacher. These can disseminate in other SMA in DIY, (c) SSP physics product development needs further development in other physics material. The hope, the ability of science process skills and problem-solving abilities of students develops, and (d) teachers can develop SSP physics products more widely to develop science process skills and mastery physics concepts. 


\section{REFERENCES}

Akinbola, A.O., \& Afolabi, F. (2010). Analysis of science process skills in west African senior secondary school certificate physics practical examinations in Nigeria. American-Eurasian Journal of Scientific Research, 5 (4), 234240.

Carin \& Sund (1990). Teaching science through discovery ( $7^{\text {th }}$ ed.) New York: Merrill Publishing Company.

Chiappetta, E. L \& Koballa, T. R., Jr. (2010). Science instruction in the middle and secondary schools. Boston: Allyn \& Bacon.

Collette, A. T. \& Chiappetta, E. L. (2007). Science instruction in the middle and secondary schools. NewYork: Macmillan.

Depdiknas. (2004). Undang-undang RI nomor 20 tahun 2003, tentang sistem pendidikan nasional. Jakarta: Balitbang Depdiknas.

Ferreira, M. M., \& Trudel, A.R. (2012). The impact of problem-based learning (PBL) on student attitudes toward science, problem-solving skills, and sense of community in the classroom. Journal of Clasroom Interaction, 47, 23-30.

Feyzioğlu, B. (2009) An investigation of the relationship between science process skills with efficient laboratory use and science achievement in chemistry education. Journal Turkish Science Education, 6, 114-132.

Feyzioğlu, B., Akyildiz, M., Demirdağ, B., Altun, E. (2012) Developing a science process skills test for secondary students: validity and reliability study. Journal Educational Sciences: Theory \& Practice, 12(3) ,18991906.

Gangoso, Z., Moyano, T., Buteler, L., Coleoni, E., Gattoni, A. (2006). Teaching strategies for physics problem solving: relations to student performance. Journal of Science Education, 7, 98-101: ProQuest Education Journals

Gok, T. (2010). The general assessment of problem solving processes and metacognition in physics education. Eurasian Journal Physics Chemistry Education, 2(2):110-122.

Goldstone, M. J. \& Downey, L. (2013). Your science clasroom: becoming an elementary/middle school science teacher. USA: SAGE Publication.

Harlen, W. (2000). Teaching, learning, and assesing science 5-12. London. Paul Chamman Pblishing Ltd. A SAGE Publication Company.

Ismail, Z. H., \& Jusoh, I (2000). Relationship between science process skills and logical thinking abilities of malaysian students.
Journal of Science and Mathematics Education in S.E. Asia, 2, 67-77.

Jacobsen, D.A, Enggen, P., \& Kauchak, D. (2009). Metode-metode pengajaran meningkatkan belajar siswa TK - SMA. (Terjemahan Achmad Fawaid \& Khairul Anam). New Jersey: Allyn \& Bacon. (Buku asli diterbitkan tahun 2009).

Jonassen, D., Strobel, J., Lee, C. B. (2006). Everyday problem solving in engineering: lessons for engineering educators . Journal of Engineering Education 95, 2, 139-151; ProQuest Education Journals.

Kemendiknas. (2010). Juknis penyusunan perangkat penilaian afektif di SMA. Jakarta: Direktorat Pembinaan SMA.

Kilen, R. (2009). Effective teaching strategies : lesson from research and practice $\left(5^{\text {th }} \mathrm{ed}\right)$. Australia: C\& C Offset printing. Co Ltd.

Liversidge, T., Cochrane, M., Kerfoot, B., \& Thomas, J. (2009). Teaching science: developing as a reflective secondary teacher. California: SAGE Publication.

Markoczi, I., \& Revak. (2003). A teaching method enhancing problem solving and motivation in secondary school. Journal of Science Education: ProQuest Education Journal,4, 1417.

Marzano, R. J. (2001). A Handbook for clasroom instruction that works. United States of America: Association for Supervision and Curriculum Development Alexandria (ASCD).

Meinser, J. S. (1999). Developing problem solving skills. Better Homes and Gardens: Apr 1999: 77, 4 Pro Quest Research Library.

Meltzer, D. E. (2002). The relationship between mathematics preparation and conceptual learning gains in physics: A possible "hidden variable" in diagnostic pretest scores. American Journal of Physics, 70, 1259-1268.

Mishra, P. \& Koehler, M. J. (2006) Technological pedagogical content knowledge: a framework for teacher knowledge. Journal Teachers College Record, 108, 1017-1054.

Moore, K. D. (2009). Effecitve Instructional Strategies from Theory to Practice. 2nd ed. California: SAGE Publication.

Muijs, D. \& Reynolds D. (2011). Effective teaching evidence and practice $\left(3^{r d}\right.$ ed.). India: Sage Publications.

Orlich, D.C., Harder, R.J., Callahan R.C., Trevisan, M.C. \& Brown, A.H. (2007). Teaching stategies : a guide to effective instruction. United States of America: Houghton Mifflin Company 
Paul Suparno. (2007). Metodologi pembelajaran fisika konstruktivistik dan menyenangkan. Yogyakarta: USD.

Selçuk, G. S., Çalışkan, S., \& Erol, M. (2008). The effects of problem solving instruction on physics achievement, problem solving performance and strategy use. Journal Physics Education, 2, 151-166.

Sukardjo. (2008). Penilaian Hasil Belajar Kimia. Yogyakarta: Program Pascasarjana Universitas Negeri Yogyakarta.

Temiz, B. K., Taşar, M., Tan, M. (2006). Development and validation of a multiple format test of science process skills. International Education Journal, 7, 14431475.
Thiagarajan, S., Semmel, D.S., Semmel, M.I. (1974). Instructional Development for Training Teachers of Expectional Children. Minneapolis, Minnesota: Leadership Training Institute/Special Education, University of Minnesota.

Wina Sanjaya. (2011) Strategi pembelajaran berorientasi pada standar proses pendidikan. Jakarta: Prenada Media Group. 